2. Wittgenstein L. Philosophische Untersuchungen. Ludwig Wittgenstein. Werkausgabe, Bd.1-8, Frankfiirt/M:Suhricamp, 1984, Bd.1,P. 394-977.

DOI https://doi.org/10.30525/978-9934-26-181-7-33

\title{
ФОРМИРОВАНИЕ ОТНОШЕНИЯ К СЕБЕ И МИРУ КАК ФАКТОР ТРАНСФОРМАЦИЙ
}

\author{
Шедяков В. Е. \\ доктор социологических наук, \\ независимый исследователь \\ г. Киев, Украина
}

\begin{abstract}
...Каждый человек может стать художником своей жизни и установить с миром - как бы это выразиться поточнее?.. - отношения взаимотворчества! ... Конечно, нелегко отличить суть жизни от суеты, тем более что «кажимость» всегда норовит выдать себя за сущиность. Но жизнь в суете, жизнь кое-как, без оглядки, когда человек не успевает задуматься, куда и зачем он идёт (да, собственно, никуда он и не идёт, хотя всё время спешит), рано или поздно мстит опустошённостью...

В.Д. Пришвина
\end{abstract}

Соответствие результата трансформаций предполагаемой модели во многом зависит не только от её качества, но и от особенностей субъекта, объекта и процесса изменений. В частности, высоко воздействие на восприятии действительности самоощущения человека и картины его представлений, во многом формируемых в ходе получения образования. От подготовки к образу жизни, воспитания самокритичности и рефлексии, качества восприятия, отправных ценностно-смысловых комплексов, постановки целей педагогики зависят не только поведенческие особенности индивида, но и вектор общественных идеологии и психологии культурно-цивилизационного мира. Социокультурный организм ойкумены может быть чреват как новой социальной жизнью, так и смертью цивилизации. При глобальном масштабе взаимодействии и накоплении оружия массового уничтожения эгоцентризм и инфантилизм, нежелание и неготовность к принятию других, отличающихся от 
собственных, интересов и подходов, губительны для человека, страны и всей ойкумены. Например, деление всех остальных на «орудие» и «помеху», выстраивание отношений вне готовности руководствоваться международной системой прав и обязательств позволяет поддерживать любого «сукина сына» если он «наш» (оценивая его как полезного для себя) и готовить свержение честных национальных лидеров на потребу корыстного истэблишмента.

Так, изменение общественных идеалов с позиций ценностного измерения бытия, культивирование многообразия мировоззрения, открытости сознания сработали как определённая интеллектуальная предпосылка нового вхождения в общественную жизнь разнообразных иррациональных факторов. Как известно, «идеальное есть... не что иное, как форма вещи, но вне вещи, а именно в человеке, в форме его активной деятельности существующая, общественно определённая форма активности человеческого существа», «совокупность осознанных индивидом всеобщих форм человеческой деятельности, определяющих, как цель и закон, волю и способность индивидов к деянию» [1, с. 216, 225]. Соответственно, возможности рациональности - структуры со своими особенностями и законами, диктующими некоторые элементы метода познания и использования превращённых форм - сейчас для использования в социальных технологиях трансформации вдвойне ограничены: и как таковой, и в условиях ризомичности развития. Отсюда - принципиальная локализация рационально организованного мышления и конструирование действительности, его явное самоограничение. Поэтому сегодняшняя практика пытается интегрировать методы рациональные и иррациональные [2-5]. Однако именно условия, которые в настоящее время создались, подталкивают ради «шкурняка» к софистике жонглирования общественным мнением и созданию популярных политических спекуляций, фриковой дипломатии и потоку фейков в СМИ.

Тем самым, заметное воздействие на итоги подвижек способна оказать триединство системы социальных педагогики, работы и управления. Укрупнённо конкурируют два пути восстановления регулируемости основных процессов целостности: через квазикастовое или же социализированное устройство общества, - каждый из которых связан со своим представлением о нормативном, справедливом и желательном в образе жизни, направлениях индивидуального и общественного изменения, структуре производства, распределения, обмена и потребления. Всякий культурно-цивилизационный мир вырабатывает и развивает в процессе истории свои особенности и представления, в частности, фиксируемые на уровнях разнообразия языковых практик, социально- 
экономических устоев, политических институтов и т.д. [7-9]. При осуществлении социально-политического программирования (в т.ч. ресурсами образования) очевидно, что сценарии реализации власти, связанные с разрушением культурного слоя цивилизации или же с наступлением на права и возможности творческой самореализации человека (тем более - его жизнь), не могут быть признаны эффективным.

Во многом картина мира преломляется в отношении к со-творчеству и самопожертвованию во имя реализации высоких идеалов и ценностей (хотя бы самоограничению и самодисциплине ради достижения общественно важных результатов). И если условия Высокого Модерна «растворяли» человека в общей судьбе, то постмодерн предоставляет гораздо больший диапазон личному выбору; «Вселенная наша - не механизм, и я, человек, участвую в непрерывном творческом процессе, который и есть жизнь. Да, мы движемся, изменяемся в этом живом потоке, хотим мы того или не хотим. Но вот как изменяемся - совершенствуемся или деградируем, это во многом, если не полностью, зависит от нас самих» [6, с. 35]: Более того: с одной стороны, степень закономерности явления, как правило, противоположна его одухотворённости, с другой же, - суть переживаемых трансформаций связана и с переходом к приоритету духовно-ментальных начал жизнедеятельности. Духовное (в частности, интеллектуальное) творчество является наиболее продуктивным, тем более - при подготовке и осуществлении «очередной промышленной революции», открывающей перспективы сочетанию возможностей человека и искусственного интеллекта. Но фактором общественной жизни становятся не задатки как таковые, а их выявление, развёртывание и просоциальная реализация, не трудовой потенциал или природные ископаемые, а мера их применения. Таким образом, задачи повышения уровня воспитания и образования входят в число важнейших требований к осуществляемому социально-политическому программированию.

\section{Литература:}

1. Ильенков Э. В. Философия и культура. М.: Политиздат, $1991.464 \mathrm{c}$.

2. Shedyakov V. Strategy of forces transformations: moral-spiritual bases of socio-economic changes. Theoretical and practical aspects of the development of the European Research Area / scient. ed. and project dir. A. Jankovska. Riga: Baltija Publishing, 2020. P. 1-26 DOI: https://doi.org/10.30525/978-9934-588-53-2-30

3. Шедяков В. Е. Гармонизация индивидуального и социального в становлении общества знания. European vector of contemporary psychology, 
pedagogy and social sciences: the experience of Ukraine and the Republic of Poland / ed. board: M. Kiedrowska, A. Erechemla, T. Branecki. Sandomierz: Baltija Publishing, 2018. Vol. 3. P. 446-470.

4. Шедяков В. Е. Реальность под давлением виртуального: взаиморезонирование материального и идеального. Нові завдання суспільних наук у XXI столітmі: Матер. Міжнар. наук.-практ. конф. Київ, 2018. C. 44-48.

5. Шедяков В. Розвиток навчання як фактор дієвості науковоосвітньо-виробничих кластерів і середовища змін. Формування ринкових відносин в Україні. 2021. Вип. 9 (244). С. 66-74. DOI: https://doi.org/10.5281/zenodo.5704591

6. Графова Л. И. Живу я в мире только раз. М.: Политиздат, 1984. $359 \mathrm{c}$.

7. Гаврилюк В. В., Трикоз Н. А. Динамика ценностных ориентаций в период социальной трансформации (поколенный подход). Социологические исследования. 2002. № 1. С. 96-105.

8. Шилов В. В., Семёнова М. Н., Сергеева Т. Н. Ценностные ориентации двух поколений. Власть. 2016. № 2. С. 141-149.

9. Шедяков В. Е. Ценностные основания национальных моделей социально-экономического развития. National Economic Reform: experience of Poland and prospects for Ukraine / ed. by A. Pawlik, K. Shaposhnykov. Kielce: Baltija Publishing, 2016. Vol. 2. P. 164-190. 